\title{
Analysis of Preference of Incentives to Innovation of Dominican Manufacturing and Service Firms
}

\author{
Victor Gómez-Valenzuela'
}

\begin{abstract}
In this paper is analyzed the structure of preference of incentives to innovation of Dominican manufacturing and services firms. The analysis of preference was carried out using a Conjoint Analysis. In total 326 firms were surveyed across the country. According to the main findings, Dominican firms prefer combinations of incentives to minimize tax liabilities but also to reduce uncertainty related to innovation activities. In terms of preference, no statistically significant differences between manufacturing and service firms were found.
\end{abstract}

Keywords: incentives; innovation; conjoint analysis; dominican republic.

'Faculty of Social Sciences and Humanities, Santo Domingo Institute of Technology Av. Los Próceres, Jardines del Norte. Santo Domingo, 10602. Dominican Republic. P. O. Box 342-9 \& 249-2, Phone +809.567.927I x 296

Santo Domingo, Dominican Republic. E-mail: victor.gomez@intec.edu

ISSN: 07 I8-2724. (http://www.jotmi.org)

Journal of Technology Management \& Innovation (C) Universidad Alberto Hurtado, Facultad de Economía y Negocios. 


\section{Introduction}

This paper aims to analyze the structure of preferences of incentives to innovation of manufacturing and service firms of the Dominican Republic. The main research questions were: I) What is the structure of preferences of incentives to innovation of Dominican firms? 2) Are there statistical differences in the structure of preference based on firms' activities and other firms' characteristics? This is a context-specific research, which means that some firms' characteristics such as size, location, tax regime and others are specific to the Dominican Republic, in the context of the Latin American and Caribbean economies. The fieldwork took place from October 2012 to May 2013, and the sample consisted of 326 firms.

This research was funded through a public interagency partnership between the National Office of Industrial Property known as ONAPI, the Dominican Fund for Social and Economic Research known as FIES (grant number 045220), and the National Competitiveness Council (C.N.C.) under the contract number $\mathrm{CO} 23 \mathrm{I} / 08 / 20 \mathrm{I}$. Also, the Dominican Republic Association of Industries and the ATABEY Innovation Centre were part of the partnership and provided logistical and technical support. In this research there were no ethical or economic conflicts.

\section{The Dominican Economy}

The Dominican Republic is a country located in the Caribbean Region and occupies two thirds of the Hispaniola Island, which is shared with the Republic of Haiti. It has a population of around 10 million of inhabitants, and a surface of close to 49,000 square kilometers (ONE, 20I I). According to the Word Bank, it is a middle income country and the largest economy of Central America and the Caribbean, with a GDP of US\$61.16 billion in 2013 (World-Bank, 2015). Until 20I0, the country experienced one of the highest growth rates in Latin America and the Caribbean (CEPAL, 2008). In terms of human development, the Dominican Republic is considered a high human development country (PNUD, 20I4), in spite of its widely recognized structural distortions in income distribution and deep social inequalities (Attali, 20I0).

Around two thirds of the economic activity consists of services, in which telecommunications and tourism play a key role. The industrial sector represents one third of the economic activity, with an important contribution of free zone firms (Banco-Central, 2013), and with a limitation in competitiveness and value creation through innovation that affects the long term possibilities of growth (Hausmann et al., 20II).

\section{Why a Conjoint Analysis?}

In ex-ante and ex-post evaluation of public policies, several techniques have been used through time. These techniques include the Delphi Method, which in general terms is based in the consensus of expert groups (Hsu \& Sandford, 2007), the Multi-criteria Analysis with a more complex quantitative approach in determining the objective function which equilibrates benefits and costs (Dooley, Smeaton, Sheath, \& Ledgard, 2009), and techniques based on opinions of experts, such as the SWOT analysis (strengths, weaknesses, opportunities, threats), which can be categorized as context-based approach (ORR, 20I I). The $C A$ provides the opportunity to combine in one technique the capabilities of groups of experts, the survey and sample design, the design of experiments and the choice modeling (Jordan J. Louviere, 1988).

\section{Some conceptual basis.}

\section{The Conjoint Analysis}

The Conjoint Analysis (CA) has been used successfully in marketing studies, in the field of health services, in transportation and infrastructure projects, in prospective studies for energy projects (Paul.E. Green \& Srinivasan, 1990), and over the last 25 years it has been intensively used in the fields of environmental economic and in the valuation and management of natural protected areas (Alpízar, Carlsson, \& Martinsson, 200I). The CA relies on the approach developed by Lancaster called the "new consumer theory", in which consumers derive utility from the characteristics or objective attributes of the goods or services such as price, size and design, instead of the goods themselves (Lancaster, 1966). The other theoretical component is called "random utility theory", which basically states that the decision-making process is conditioned by the random or unobservable characteristics that lie behind the choices or the preference, such as personal tastes, education or incomes, in the case of consumers (Boxall,Adamowicz, Swait, Williams, \& Louviere, 1996).

The CA is classified as a measure of dominance, which consists in numerical assignments to analyze the degree of preference between certain objects (J. J. Louviere, Hensher, \& Swait, 2010). There are different types of CA to allow alternative options of analysis of preferences such as: I) the discrete selection of an option against other competitive options; 2) more dichotomous choices such as "Yes" or "No"; 3) sorting options (order of most preferred to least preferred), among other (Boyle, Holmes, Teisl, \& Roe, 200I). 


\section{Fiscal incentives in STI policy}

For the purpose of this research, incentives can be defined as policy instruments to support changes in the behavior of firms, encouraging them to move towards certain objectives of public policies (Scotchmer, 2004). One of the roles of policy institutions in an NSI is precisely to promote innovative behavior in firms through incentives (Edquist \& Johnson, 1997), by offering basically two types of incentives: monetary and non-monetary incentives. The former includes systems of intellectual property protection (Scotchmer, 2004), and the latter includes fiscal incentives and other mechanisms of direct public funding such grants and subsidies (Rivas Sánchez, 2007). The fiscal incentives provide facilities to ease tax liabilities and can operate in two areas: on the tax base (property subject to taxation) and on the tax debt, which is the amount payable as results of tax liabilities incurred in a given period (Rivas Sánchez, 2008).

According to the evidence available in the context of the OCED economies, tax incentives to innovation have a positive effect on the innovative behavior of firms (Guellec \& van Pottelsberghe de la Potterie, 2002). In the context of Latin America and the Caribbean, two contributions have special relevance: the contribution of Park on the diffuse impact of tax incentives to innovation in LAC economies (Park, 2002), and the evidence of the crowdingout effect of government support to activities such as R\&D (Dominguez, 2008).

In the LAC region, research on STI policies and particularly on tax incentives and their effect on the innovative behavior of firms, has been disperse, and has been undertaken mainly from the perspective of the supply side of policies and in the context of regional cooperation and funding agencies (Vonortas, 2002). The specific contribution of this research is to explore the perspective of firms' preferences of incentives to innovation in the specific context of the Dominican Republic.

\section{Methodology.}

\section{Defining attributes and levels}

Two experts workshops were conducted in order to define attributes and levels, which is a recommended approach when there isn' $t$ a clear background of the combination of attributes and levels to be presented as choice sets (P. E. Green, Krieger, \& Wind, 200I).

The first workshop was conducted in November of $201 \mathrm{I}$ in Santo Domingo, Dominican Republic. Eight public officials participated in this workshop, from the following offices: the National Tax Bureau, the National Custom Agency, the National Office of Industrial Property, the National Competitiveness Council, the Ministry of Higher Education, Science and Technology and PROINDUSTRIA, which is the national agency that manages the system of incentives to innovation. The second workshop took place on July 3rd of 2012, in the Complutense Institute of International Studies, in Madrid, Spain, and included the participation of six experts from the Complutense University, the Autonomous University of Madrid and the European University of Madrid. In the first workshop, the experts analyzed a matrix of 14 attributes and their corresponding levels. This first matrix was based on the Dominican tax framework on monetary and fiscal incentives and in several acts, such as the "Competitiveness and Innovation Act" (392-07); the "Higher Education, Science and Technology Act" (I39-0I), and in the "Industrial Property Act" (20-00). In the first workshop, the matrix was reduced to 12 attributes, and in the second one the resulting matrix from the first workshop was reduced to only 8 attributes, which are shown in table I. The only exception was the attribute on intellectual property and its levels, which was based on the figure of patent box as tax incentive (Atkinson \& Andes, 20l I). All attributes and levels were re-arranged by the experts as shown in table $\mathrm{I}$.

All attributes and their levels were defined and explained in the clearest manner possible, in order to reduce ambiguity and communicate the purpose of the CA to firms. In terms of design, the matrix in table I would produce a complex factorial defined as $25 \times 32 \times 4=1,152$ of possible combinations or profiles, which is an impractical amount of combinations to be elicited. In order to reduce the number of profiles in an efficient way, it was necessary to carry out a fractional orthogonal design, which consists on finding the optimal number of combinations (DeShazo \& Fermo, 2002).

A design is considered orthogonal when it has three characteristics: I) there is no correlation of attributes and levels; 2) is balanced, meaning that the levels of each attribute appear with equal frequency in the design, and 3) it has a minimum overlap, which means that a level of an attribute is not repeated in a series of alternatives. This must result in a balance of utility of the choice sets or profiles, implying that the expected utility of each alternative within a set of selection is the same (Huber \& Zwerina, 1996). To generate an orthogonal fractional design, the ORTHOPLAN procedure of SPSS $\odot 20$ was used, allowing a full profile design with orthogonal fractioning and principal effects. The exercise resulted in 18 optimal profiles or choice sets: sixteen of these were used to be elicited by firms and two were used for simulations. 


\begin{tabular}{|l|l|l|}
\hline$\#$ & Attributes & Levels \\
\hline I & $\begin{array}{l}\text { Tax deferred based on benefits gener- } \\
\text { ated by R\&D and innovative activities }\end{array}$ & $\begin{array}{l}\text { With tax deferred } \\
\text { Without tax deferred }\end{array}$ \\
\hline 2 & $\begin{array}{l}\text { Tax deduction based on innovation, } \\
\text { R\&D and other innovative activities. }\end{array}$ & $\begin{array}{l}\text { With tax deduction } \\
\text { Without tax deduction }\end{array}$ \\
\hline 3 & $\begin{array}{l}\text { Amortization (depreciation) of capital } \\
\text { goods based on R\&D and others inno- } \\
\text { vative activities }\end{array}$ & $\begin{array}{l}\text { Planned accelerated depreciation } \\
\text { Free accelerated depreciation } \\
\text { Without accelerated depreciation }\end{array}$ \\
\hline 4 & $\begin{array}{l}\text { Tax credit based on the total expendi- } \\
\text { ture on innovation, R\&D and other in- } \\
\text { novative activities. }\end{array}$ & $\begin{array}{l}\text { With tax credit } \\
\text { Without tax credit }\end{array}$ \\
\hline 5 & $\begin{array}{l}\text { Tax exemption based on R\&D and other } \\
\text { collaborative innovative activities. }\end{array}$ & $\begin{array}{l}\text { Collaboration with other firms } \\
\text { Collaboration with universities \& } \\
\text { search centers } \\
\text { Collaboration with foreigner organiza- } \\
\text { tions } \\
\text { Without tax exemption }\end{array}$ \\
\hline 6 & $\begin{array}{l}\text { Guarantee funds for innovation and } \\
\text { technology transfer projects }\end{array}$ & $\begin{array}{l}\text { With guarantee funds } \\
\text { Without guarantee funds }\end{array}$ \\
\hline 7 & $\begin{array}{l}\text { Public Funds for co-financing R\&D and } \\
\text { innovative activities } \\
\text { and firms }\end{array}$ & $\begin{array}{l}\text { Public funds as a low rate loan } \\
\text { Public funds as subsidy } \\
\text { Without public funds at all }\end{array}$ \\
\hline
\end{tabular}

Table I. Attributes and levels 


\section{Control variables}

The control variables were defined to support the analysis of preferences, and refer to basic characteristics of firms. With the collaboration of experts of Santo Domingo and Madrid, 10 categorical control variables were defined: I) Region (Santo Domingo Metro, North region, East region and South); 2) Localization (urban or rural); 3) Tax regime (ordinary and free zones); 4) Age of firms (young, adult and mature); 5) Capital composition (full national; 10\%$50 \%$ national; $50 \%-75 \%$ foreigner; full foreigner); 6) Firm size based on the number of workers (small, medium and large); 7) Activity (manufacturing, service); 8) Main market (local, national, regional, international); 9) Technological level of product/services (high level, medium high level, medium low level, low level); and 10) Product/services life cycle (short: <I year, medium: I-3 year, long: > 3 years). Two of them ("ages of firms" and "technological levels of product/ services") were taken from literature. The former was taken from Berger \& Udell (1998), which classified age of firms into three groups: 0-4 years, 5-24 years and more than 25 years. The latter was taken from the classification of manufacturing industries according to their technological intensity, in which products could be classified as: high-tech, medium-high technology, medium-low technology and low technology (Hatzichronoglou, 1997).

In the case of the variable "firm size" the Dominican definition, which is based on number of workers, does not fit with international standards such as the OECD criteria (OECD, 2005). According to the Dominican Law, micro business are composed of $1-15$ workers, small business of 16-60, medium businesses of 61-200 and large firms of more than 201 workers (R. Guzmán \& Ortíz, 2007). The final survey was piloted on 40 firms, which evaluated the survey and suggested changes that were taken into account for the final fieldwork.

\section{Analysis of preferences}

For the analysis of preferences, the CA procedure selected was the decompositional approach. This approach is based on the premise that different levels of attributes make a partial contribution (part-worths) to the total utility, and the obtained scores are equivalent to the regression coefficients and indicate the relative importance of each attribute (P. E. Green et al., 200I). Then, the structure of preferences is estimated by an ordinary least square (Sen), which has a linear and additive form that can be represented as follows:

$$
y_{i}=a+\sum_{i=1}^{I} \sum_{j=1}^{k_{i}} \beta_{i j} x_{i j}+\varepsilon_{t}
$$

In expression I, yi represents the ranking of preferences of different profiles to which the firm is exposed; $\alpha$ represents the constant generated by the method of OLS; $\beta i j$ represents the utilities or part-worths associated with different levels of attributes; and xij represents the presence or absence of a given level of attribute in the generated profiles. In simple terms, firms would select profiles or combinations of levels, taking into account that certain levels are more appealing than others and these levels will neutralize those with low attractiveness that otherwise would not have been selected (Huber \& Zwerina, 1996).

The part-worths can reduce their own contribution to zero, which would indicate the lowest preference of some levels, and therefore, the minimum contribution to the expected total utility. They also could achieve the maximum score indicating the highest level of preferences, which implies that the selection of a particular profile would be conditioned by the attractiveness of a particular level of an attribute in relation to other levels present in the profile (Huber \& Zwerina, 1996).

\section{Segmentation of preferences}

In the CA, the disaggregation of preferences is called "segmentation". It helps to analyze differences in preferences inside the collected sample, and can be done in two ways: a priori and post hoc (Picón Prado \& Varela Mallou, 2000). In the former, the number of segments, their sizes and characteristics are defined in the design stage of the research, based on the literature review of similar cases and on the experience of the researcher. In the latter, the number of segments and their characteristics are defined after the sample is obtained, according to one or more classification variables or by cluster analysis (Rivera Deán, González Tabares, Martín Santana, Oñate García, \& Sánchez Fernández, 2004).

In the post hoc segmentation, a separately CA is performed to the resulting groups to compare the differences in preferences between them (Ramírez Hurtado, Rondán Cataluña, \& Guerrero Casas, 2007). In the case of this research and given its exploratory nature, the two types of segmentations were carried out: an a priori segmentation based on firms activities, and a post hoc segmentation based on cluster analysis.

\section{Forecasting preferences}

The procedure CONJOINT of SPSS uses three models to estimate the probability of choice: I) the total utility model or TU; 2) the Bradley-Terry-Luce model or BTL and, 3) the logit model which has been used in several types of Conjoint Analysis (Paul. E. Green \& Srinivasan, 1990). In order to

ISSN: 07I 8-2724. (http://www.jotmi.org) 
perform a simulation of probabilities of choice, the last two profiles generated during the orthogonal design were utilized. The TU model estimates the probability of choice assuming that the profile with the highest total utility will be the most likely to be chosen (MacFadden, 1980). The selection of the profile with the highest utility follows a relatively simple binary approximation which can be represented as indicated in expression 2 (Ramírez Hurtado et al., 2007).

$$
p i=\left\{\begin{array}{l}
1 \operatorname{yes}_{i}=\max \left(i_{n} \in k_{i \ldots n}\right) \\
2 n o U_{i}=\min \left(i_{n} \in k_{i \ldots n}\right)
\end{array}\right.
$$

The BTL model estimates the probability of choosing by comparing the profiles with the highest utility in relation to the others, and then averaging the balance of utility of respondents and also the probability of choice of all profiles (Huber, Wittink, Fiedler, \& Miller, 1993). The functional expression of the BTL model can be represented as:

$$
p_{i}=\frac{\hat{r}_{i}}{\sum_{j=1}^{J} \hat{r}_{i}}
$$

In expression 3, J represents the total number of profiles. In other words, the probability of choosing a specific combination of levels is given by the utility provided for the sum of all combinations. The third model used by the CONJOINT procedure, the logit model, is the most popular approach in choice experiments (Hanley, Wright, \& Adamowicz, 1998). The logit model assumes that preferences are linear, and unlike the BTL it uses a natural logarithm of the utilities to estimate the probabilities of choice. The functional expression can be represented as follows:

$$
P_{n i}=\frac{\exp ^{\mu L_{n i}}}{\sum_{i \in S} \exp ^{\mu L_{n i}}}
$$

In expression 4, the probability that profile Lni was selected by the firm $n$ depends on the observable part of the expected utility function of the selected profile, related to the set of alternatives that makeup the set of options S. In this function, $\mu$ is a scale parameter associated with the distribution of the utility function, theoretically equal to I (Hanley, Mourato, \& Wright, 200I).

\section{Sample size}

As it has been stated, 326 firms were sampled from a universe of 6,877 firms. This universe of 6,977 firms was taken from the database provided by the Dominican Association of Industries (AIRD for its acronyms in Spanish) and by the National Tax Bureau known in Spanish as "Dirección Nacional de Impuestos Internos". The sample design chosen was a simple random design with proportional allocation by regions and activities (Scheaffer, Mendenhall, \& Ott, 2007). The confidence level was of $95 \%$ and the margin of error of $5 \%$.

According to literature, the sample size for CA studies tends to vary in a range between 100 to 1000 subjects, and the most typical samples sizes tend to be in a range of 300 to 550 cases, usually for commercial studies (Alpízar et al., 200I). Therefore, the reached sample has the typical range for CA studies.

\section{Results}

In regards to their general characteristics, the surveyed firms are distributed as follows: $66.3 \%$ are located in the metropolitan area of Santo Domingo, and the remaining $33.7 \%$ distributed in the other regions; $93.6 \%$ of the firms are located in urban areas and the remaining $6.3 \%$ are located in rural areas. Based on the number of workers, in the Dominican context $82.5 \%$ of the firms are considered small, $12 \%$ are considered medium-size and $5.5 \%$ are considered large, reflecting the composition of the Dominican industrial sectors (R. M. Guzmán, 20I I). In regards to the tax regime, $90 \%$ of firms operate in the regular tax system while $10 \%$ operate in the free zone tax regime. In regards to their age, $62.6 \%$ of firms are considered "adults" (between 5 and 24 years), $31.6 \%$ are mature (over 25 years) and only $5 \%$ are young firms ( 0 to 4 years). According to their activity, $57 \%$ are manufacturing firms and $43 \%$ belong to the service sector.

Concerning the capital structure, $86.2 \%$ of the firms are $100 \%$ Dominican, $7.4 \%$ have a variable mix of Dominican and foreign capital and the reining $6.4 \%$ are of foreign capital. Related to the target market, $89.5 \%$ of the companies are focused on the domestic market and the remaining $10.5 \%$ target the international market. In relation to the degree of sophistication of products/services, $15 \%$ of the surveyed firms affirmed to offer products/services with high tech content, $34.7 \%$ stated to offer products with a medium-high level of tech content, $20.9 \%$ indicated to offer products with a medium-low level of tech content, and $29.4 \%$ affirmed to offer products/services with low level of tech content. 
In regards to the life cycle of products, $25.5 \%$ of the surveyed firms affirmed to offer product/services of a short life cycle (<1 year), $21.5 \%$ affirmed to offer product/services of medium life cycle ( $1-3$ years), and $39.6 \%$ stated that they offer products/ services of a long life cycle ( $>3$ years).

\section{Aggregate analysis of preferences}

The aggregate analysis of preferences is intended to provide an overall view of the structure of preferences of manufacturing and service firms, which provides an answer to the first research question. The CONJOINT procedure offers the following outputs: I) a description of the factors (attributes), 2) correlations of observed and estimated preferences, 3) the part-worths or partial contributions of level of attributes, and 4) the relative importance of attributes as shown in table $2 \& 3$.
Table 2 presents the factors or attributes used to evaluate preferences, indicating that all attributes are discrete and orthogonal, which means that the full profile design was efficient. Table 3 indicates that observed and estimated preferences are correlated, which means that the variables of preference have a good fit (Ramírez Hurtado et al., 2007).

\begin{tabular}{|l|c|c|}
\hline \multicolumn{3}{|c|}{ Correlations* } \\
\hline \multicolumn{1}{|c|}{ Measures } & Value & Sig. \\
R Pearson & 0,906 & 0,000 \\
\hline Tau Kendall & 0,750 & 0,000 \\
\hline \multicolumn{2}{|c|}{$*$ Correlations between observed and } \\
estimated preferences \\
\hline
\end{tabular}

Table 3. Correlation of the expected preferences

\begin{tabular}{|l|c|c|}
\hline \multicolumn{1}{|c|}{ Factors in the model } & Levels & Kind of factors \\
\hline 1. Tax deferred based on benefits of innovation and R\&D & 2 & Discrete \\
\hline $\begin{array}{l}\text { 2. Tax deduction based on innovation, R\&D and other } \\
\text { innovative activities }\end{array}$ & 2 & Discrete \\
\hline $\begin{array}{l}\text { 3. Amortization (depreciation) of capital goods of R\&D } \\
\text { and others innovative projects }\end{array}$ & 3 & Discrete \\
\hline $\begin{array}{l}\text { 4. Tax credit based on the total expenditure on R\&D on } \\
\text { other innovative activities }\end{array}$ & 2 & Discrete \\
\hline $\begin{array}{l}\text { 5. Tax exemption based on R\&D and other innovative } \\
\text { collaborative activities }\end{array}$ & 4 & Discrete \\
\hline $\begin{array}{l}\text { 6. Guarantee funds for innovation and tech transfer } \\
\text { projects }\end{array}$ & 2 & Discrete \\
\hline $\begin{array}{l}\text { 7. Public funds for co-financing R\&D and innovation } \\
\text { projects }\end{array}$ & 3 & Discrete \\
\hline $\begin{array}{l}\text { 8. Tax decuction based on IP transfer among universities } \\
\text { and firms }\end{array}$ & 2 & Discrete \\
\hline
\end{tabular}

*All factors are orthogonal

Table 2. Factors in the estimated aggregated model 


\begin{tabular}{|c|c|c|c|}
\hline $\begin{array}{l}\text { Coeff. } \\
\mathbf{a}_{0}\end{array}$ & $\begin{array}{c}\text { Level of attributes } \\
\text { Constant } \\
\end{array}$ & $\begin{array}{l}\text { Part-worths } \\
\mathbf{8 , 5 1 8}\end{array}$ & $\begin{array}{l}\text { Error } \\
\mathbf{0 , 4 2 5}\end{array}$ \\
\hline$\beta_{1}$ & Tax deferral based on $\mathrm{R} \& \mathrm{D}$ and innovative activities & 0,216 & 0,385 \\
\hline$\beta_{2}$ & No tax deferral based on R\&D and innovative activities & $-0,216$ & 0,385 \\
\hline$\beta_{3}$ & Tax deduction based on R\&D and innovative activities. & 0,374 & 0,385 \\
\hline$\beta_{4}$ & No tax deduction based on R\&D and innovative activities & $-0,374$ & 0,385 \\
\hline$\beta_{5}$ & $\begin{array}{l}\text { Accelerated depreciation of capital goods based on R\&D and } \\
\text { innovative activities }\end{array}$ & $-0,155$ & 0,513 \\
\hline$\beta_{6}$ & $\begin{array}{l}\text { Free accelerated depreciation of capital goods based in } R \& D \\
\text { and innovative activities }\end{array}$ & $-0,672$ & 0,601 \\
\hline$\beta_{7}$ & $\begin{array}{l}\text { No accelerated depreciation of capital goods based on } \\
\text { R\&D and innovative activities }\end{array}$ & $\mathbf{0 , 8 2 7}$ & 0,601 \\
\hline$\beta_{8}$ & $\begin{array}{l}\text { Tax credit based on total expenditure on } R \& D \text { an innovative } \\
\text { activities }\end{array}$ & $-0,616$ & 0,385 \\
\hline$\beta_{9}$ & $\begin{array}{l}\text { No tax credit based on expenditures on } R \& D \text { and innovative } \\
\text { activities }\end{array}$ & 0,616 & 0,385 \\
\hline$\beta_{10}$ & $\begin{array}{l}\text { Tax exemption based on innovative collaborative activities } \\
\text { with other firms }\end{array}$ & $-0,937$ & 0,666 \\
\hline$\beta_{11}$ & $\begin{array}{l}\text { Tax exemption based on collaborative activities among } \\
\text { universities and research centers }\end{array}$ & 0,910 & 0,666 \\
\hline$\beta_{12}$ & $\begin{array}{l}\text { Tax exemption based on collaborative activities with foreigner } \\
\text { entities }\end{array}$ & 0,501 & 0,666 \\
\hline$\beta_{13}$ & No tax exemption based on collaborative innovative activities & $-0,474$ & 0,666 \\
\hline$\beta_{14}$ & Guarantee funds for innovation \& tech transfer projects & 0,714 & $\mathbf{0 , 3 8 5}$ \\
\hline$\beta_{15}$ & No guarantee funds for innovation and tech transfer projects & $-0,714$ & 0,385 \\
\hline$\beta_{16}$ & $\begin{array}{l}\text { Public funds as low rate loan for co-financing innovation and } \\
\text { tech transfer projects }\end{array}$ & 0,082 & 0,513 \\
\hline$\beta_{17}$ & $\begin{array}{l}\text { Public funds as subsidies for co-financing R\&D and other in- } \\
\text { novative activities }\end{array}$ & 0,167 & 0,601 \\
\hline$\beta_{18}$ & $\begin{array}{l}\text { No public funds for co-financing R\&D, tech transfer projects } \\
\text { and other innovative activities }\end{array}$ & $-0,249$ & 0,601 \\
\hline$\beta_{19}$ & $\begin{array}{l}\text { Tax deduction based on intellectual property transfer among } \\
\text { universities and firms }\end{array}$ & 0,291 & 0,385 \\
\hline$\beta_{20}$ & $\begin{array}{l}\text { No tax deduction based on IP transfer among universities and } \\
\text { firms }\end{array}$ & $-0,291$ & 0,385 \\
\hline
\end{tabular}

Table 4. Part-worths of levels of incentives to innovation at aggregated level of firms) 
Table 4 shows the most important results of the research, which are the structure of preferences of incentives to innovation. The part-worths are equivalent to the coefficients of a regression model, in which the positive scores indicate a higher expected utility and the negative ones indicate an aversive expectation or rejection (Boyle et al., 200 I). In the table 4 the three most valued levels by firms are highlighted in bold, and the three most rejected in italic. An interesting finding to be highlighted is the positive valuation of the collaboration between firms with universities and research centers, in contrast with the unwillingness to collaborate with other firms. In regards to the relative importance of attributes by themselves, chart I shows the preferences of the surveyed firms.

\section{Segmentation of preferences}

Two segmentations were made: a priori and post-hoc, in order to provide an answer to the second research question. The first one shows the preferences based on activities and the second shows the preferences based on cluster analysis. The segmentation based on activities is shown in tables 5 and 6.

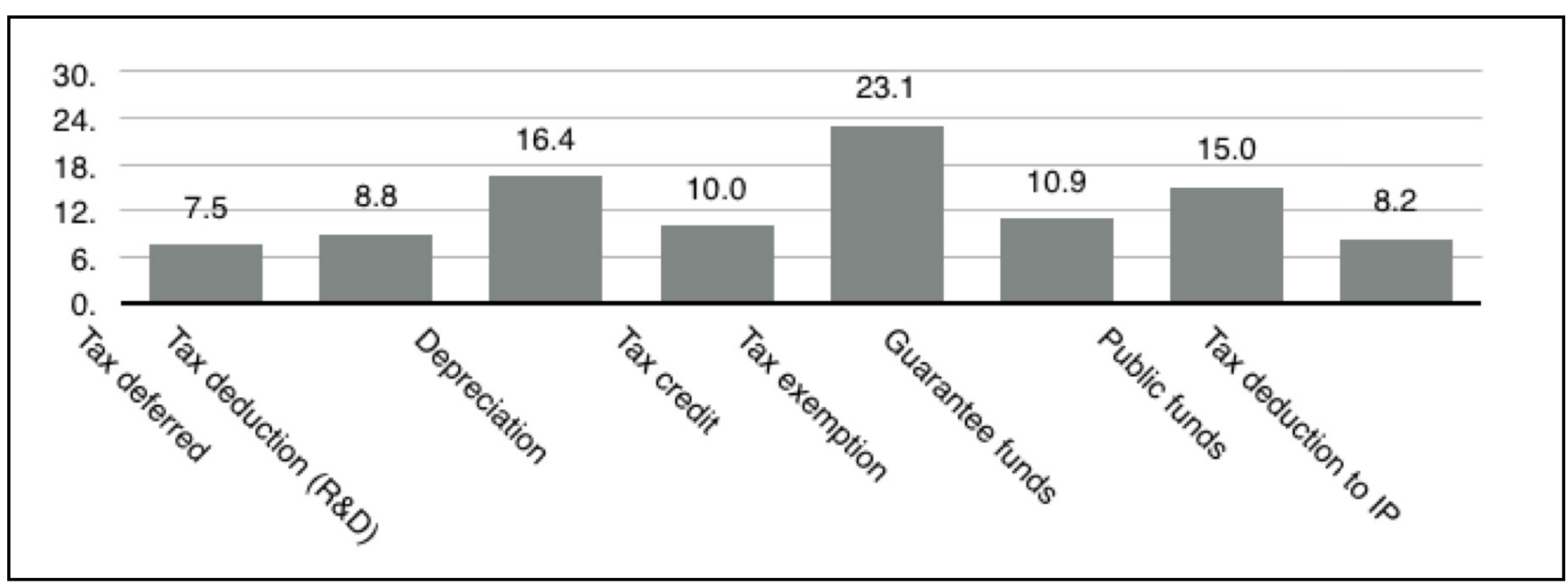

Chart I. Relative importance (\%) of attributes at the aggregated level of firms

\begin{tabular}{|c|c|c|}
\hline \multicolumn{3}{|c|}{ Correlations* } \\
\hline Measures & Manufacturing & Services \\
\hline R Pearson & 0,926 & 0,872 \\
\hline Sig. & 0,000 & 0,000 \\
\hline Tau Kendall & 0,778 & 0,717 \\
\hline Sig. & 0,000 & 0,000 \\
\hline *Correlations between observed and \\
estimated preferences \\
\hline
\end{tabular}

Table 6. Part-worths of level of incentives of manufacturing and service firms 
Table 5 shows the correlations among observed and estimated preferences of both manufacturing and service firms. In both types of firms the correlation indicates that the variables of preference have a good fit, but slightly better in manufacturing firms than in the case of service firms. Regarding to the most important output shown in table 6 , it can be appreciated that, although the levels of attributes report some differences between manufacturing and service firms, the total utility is very similar, as it has been reported in other CA studies (Ramírez Hurtado et al., 2007). In table 6 , the attributes with the highest scores are emphasized in bold, and the worst ranked in are emphasized in italic. Some scores show interesting findings, such as the $\beta$ I level, where the utility is visibly lower for service firms than for manufacturing firms, and the $\beta 3$ level, which generates more utility for manufacturing than for service firms. Chart 2 shows the relative importance of attributes for both types of firms.

Examining the attributes, it is obvious that both types of firms have a converging structure of preferences. However, given the observed differences in the structure of preferences in table 6 and despite the similarities shown in chart 2, the central question is whether the differences in preference of attributes between both types of firms will become statistically significant.
According to the performed ANOVA test (P. E. Green \& Srinivasan, 1978), no statistically significant differences were found in the preference structure of levels of attributes in the two types of firms (Annex I).

Related to the post-hoc segmentation via cluster analysis, two combined procedures were used to enforce the segmentation process, following several authors: k-means and discriminant analysis (Sánchez \& Gil, 1998). As a result, two clusters were defined: 186 firms were included in the first cluster and 137 in the second cluster, and 3 firms were disregarded. One of the most relevant differences between cluster $I$ and cluster 2 is that in cluster I there are more service firms and medium sized-firms than in cluster 2; and in cluster 2 there are more manufacturing firms and smallsized firms than in cluster I. Table 7 shows the part-worths corresponding to clusters I and 2. (Insert table 7)

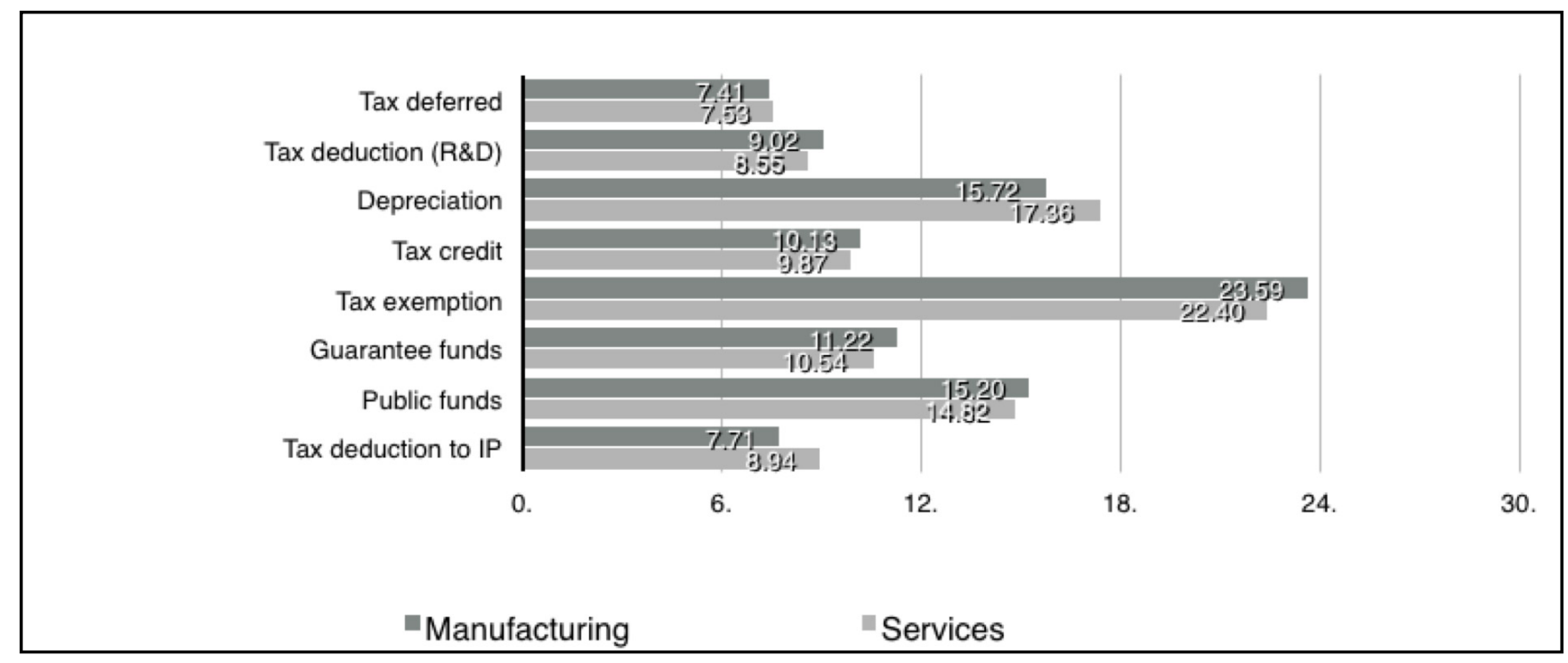

Chart 2. Relative importance (\%) of attributes for manufacturing and services firms 


\begin{tabular}{|c|c|c|c|}
\hline \multirow{2}{*}{ Coeff. } & \multirow{2}{*}{ Levels of attributes } & \multicolumn{2}{|c|}{ Part-Worths } \\
\hline & & Cluster 1 & Cluster 2 \\
\hline$a_{0}$ & Constant & 8,504 & 8,564 \\
\hline$\beta_{1}$ & Tax deferral based on R\&D and innovative activities & 0,151 & 0,321 \\
\hline$\beta_{2}$ & No tax deferral based on R\&D and innovative activities & $-0,151$ & $-0,321$ \\
\hline$\beta_{3}$ & Tax deduction based on R\&D and innovative activities. & 0,445 & 0,308 \\
\hline$\beta_{4}$ & No tax deduction based on R\&D and innovative activities & $-0,445$ & $-0,308$ \\
\hline$\beta_{5}$ & $\begin{array}{l}\text { Accelerated depreciation of capital goods based on R\&D and } \\
\text { innovative activities }\end{array}$ & 0,005 & $-0,434$ \\
\hline$\beta_{6}$ & $\begin{array}{l}\text { Free accelerated depreciation of capital goods based in } R \& D \\
\text { and innovative activities }\end{array}$ & $-0,820$ & $-0,422$ \\
\hline $\mathbf{B}_{7}$ & $\begin{array}{l}\text { No accelerated depreciation of capital goods based on } R \& D \\
\text { and innovative activities }\end{array}$ & 0,815 & 0,856 \\
\hline$\beta_{8}$ & $\begin{array}{l}\text { Tax credit based on total expenditure on R\&D an innovative } \\
\text { activities }\end{array}$ & $-0,547$ & $-0,705$ \\
\hline$\beta_{9}$ & $\begin{array}{l}\text { No tax credit based on expenditures on } R \& D \text { and innovative } \\
\text { activities }\end{array}$ & 0,547 & 0,705 \\
\hline$\beta_{10}$ & $\begin{array}{l}\text { Tax exemption based on innovative collaborative activities } \\
\text { with other firms }\end{array}$ & $-0,974$ & $-0,876$ \\
\hline $\mathbf{B}_{11}$ & $\begin{array}{l}\text { Tax exemption based on collaborative activities among uni- } \\
\text { versities and research centers }\end{array}$ & 0,934 & 0,890 \\
\hline$\beta_{12}$ & $\begin{array}{l}\text { Tax exemption based on collaborative activities with foreigner } \\
\text { entities }\end{array}$ & 0,473 & 0,505 \\
\hline$\beta_{13}$ & No tax exemption based on collaborative innovative activities & $-0,432$ & $-0,519$ \\
\hline $\mathbf{B}_{14}$ & Guarantee funds for innovation \& tech transfer projects & 0,673 & 0,765 \\
\hline$\beta_{15}$ & No guarantee funds for innovation and tech transfer projects & $-0,673$ & $-0,765$ \\
\hline$\beta_{16}$ & $\begin{array}{l}\text { Public funds as low rate loan for co-financing innovation and } \\
\text { tech transfer projects }\end{array}$ & $-0,021$ & 0,179 \\
\hline$\beta_{17}$ & $\begin{array}{l}\text { Public funds as subsidies for co-financing R\&D and other in- } \\
\text { novative activities }\end{array}$ & 0,210 & 0,160 \\
\hline$\beta_{18}$ & $\begin{array}{l}\text { No public funds for co-financing } \mathrm{R} \& \mathrm{D} \text {, tech transfer projects } \\
\text { and other innovative activities }\end{array}$ & $-0,189$ & $-0,340$ \\
\hline$\beta_{19}$ & $\begin{array}{l}\text { Tax deduction based on intellectual property transfer among } \\
\text { universities and firms }\end{array}$ & 0,324 & 0,229 \\
\hline$\beta_{20}$ & $\begin{array}{l}\text { No tax deduction based on IP transfer among universities and } \\
\text { firms }\end{array}$ & $-0,324$ & $-0,229$ \\
\hline & $\begin{array}{l}\text { Total utility } \\
\end{array}$ & 8,505 & 8,563 \\
\hline
\end{tabular}

Table 7. Part-worths of level of incentives of innovation in clustered firms 
The differences in the structure of preference in cluster I and 2 are quite obvious in the coefficients for both positive and negative part-worths. Table 7 shows the attributes with the highest part-worts in bold and the worse ranked in italic. Two levels of attributes stand out: in the score of $\beta 5$ the part-worths for cluster $I$ is positive and for cluster 2 is negative, and it is the opposite for $\beta 16$, in which the score is negative for cluster $I$ and positive for cluster 2 . This highlights the differences in structure of preferences despite the fact that the total utility is similar. Chart 3 shows the relative importance of attributes for the clusters.

In regards to the statistical differences in the structure of preferences of attributes for innovation, the ANOVA test (Annex 2) shows statistically significant differences on preferences in the two clusters contrasting with the results of the a priori segmentation.

The a priori segmentation did not find statistical differences between groups taking into account their activities. This does not imply that such differences don't exist, but it does indicate that these differences are not statically significant. However with the post-hoc segmentation such differences were found, given the more stylized way in grouping firms by this cluster analysis technique (Picón Prado \& Varela Mallou, 2000). The key issue here is that despite the similarity of the structure of preferences of the two segmentation groups, it may not make sense to compare them because they are the result of a different decision making process which cannot be transferred between groups (Geanakoplos, 1996). Related to firm's characteristics and the preferences of incentives to innovation, and based on the MANOVA test (Steven, 1980), in the case of manufacturing firms the characteristic "size" seems to affect the election. In the case of service firms, two characteristics seem to affect the election: tax regime and capital composition (Annex 3).

\section{Forecasting preferences}

As it has been stated before, 18 profiles of level of attributes were generated using the CONJOINT procedure. Two of the 18 profiles were not evaluated by firms and were used to codify a simulation on the probability of choice by using the three models explained before: the Total Utility model, the BTL model and the logit model. Table 8 shows the probability of choice based on the estimations of the three models, and table 9 shows the composition of the analyzed profiles based on the aggregate level of analysis of preferences.

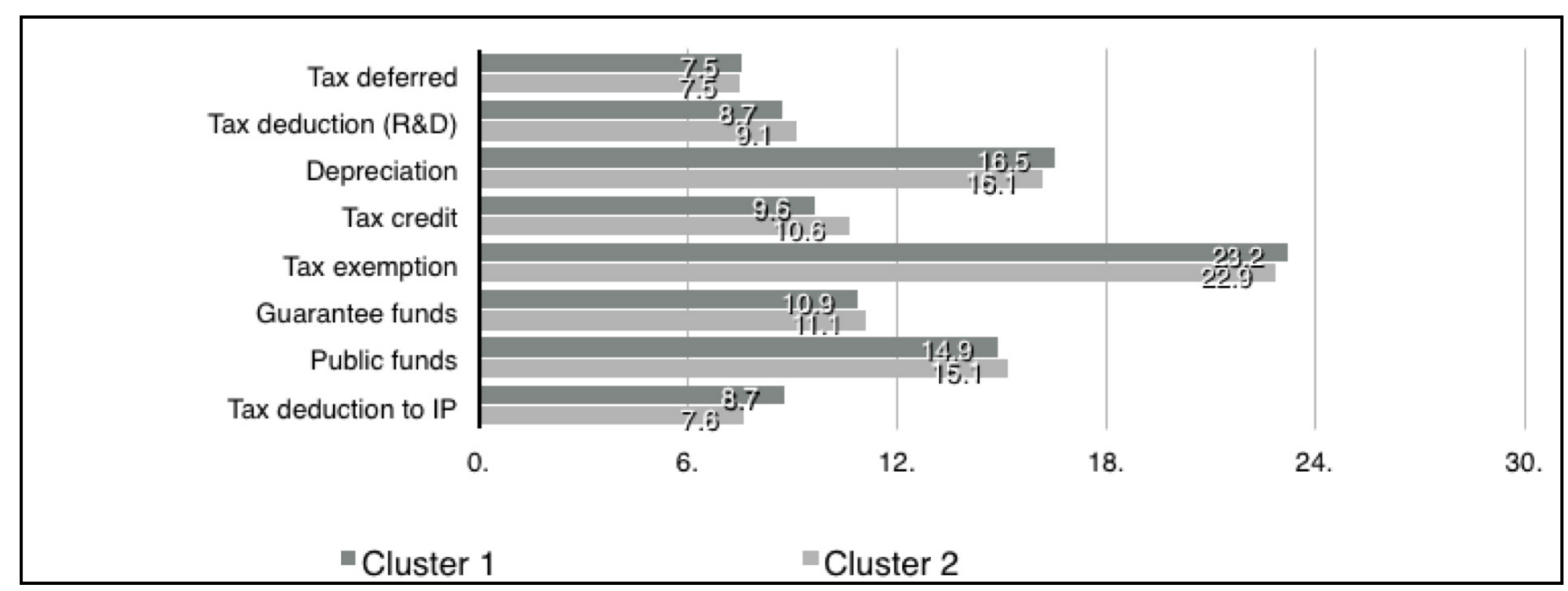

Chart 3. Relative importance (\%) of attributes for clusters I and 2

ISSN: 07I 8-2724. (http://www.jotmi.org) 
According to the three probabilistic models in table 8, profile I was the most the selected given its specific composition of levels of attributes. The two profiles share the same part-worths for the first four levels, but after the fourth level strong differences arise (Table 9). At the aggregate level of preferences and in the context of the Dominican Republic, the simulation indicates that firms will prefer those combinations that maximize direct public funding. In regards to the probabilities of choice based on firm's segmentation, the results are quite similar to the aggregate level of preferences, and are shown in Table 10.

\begin{tabular}{|c|c|c|c|c|}
\hline \multicolumn{5}{|c|}{ Probabilities of choice } \\
\hline Profiles & ID & TU model & $\begin{array}{c}\text { Bradley-Ter- } \\
\text { ry-Luce }\end{array}$ & Logit \\
\hline 17 & I & $77,90 \%$ & $61,60 \%$ & $73,50 \%$ \\
\hline 18 & 2 & $22,10 \%$ & $38,40 \%$ & $26,50 \%$ \\
\hline
\end{tabular}

Table 8. Probabilities of choices of the simulation profiles at the aggregated level

\begin{tabular}{|c|c|c|c|}
\hline \multicolumn{2}{|l|}{ Profile 17} & \multicolumn{2}{|l|}{ Profile 18} \\
\hline Level of attributes & $\begin{array}{c}\text { Part- } \\
\text { worths }\end{array}$ & Level of attributes & $\begin{array}{c}\text { Part- } \\
\text { worths }\end{array}$ \\
\hline $\begin{array}{l}\text { I. No tax deferral based on R\&D and } \\
\text { innovative activities }\end{array}$ & $-0,216$ & $\begin{array}{l}\text { I. No tax deferral based on R\&D } \\
\text { and innovative activities }\end{array}$ & $-0,216$ \\
\hline $\begin{array}{l}\text { 2. Tax deduction based on R\&D and inno- } \\
\text { vative activities. }\end{array}$ & 0,374 & $\begin{array}{l}\text { 2. Tax deduction based on R\&D } \\
\text { and innovative activities. }\end{array}$ & 0,374 \\
\hline $\begin{array}{l}\text { 3. Accelerated depreciation of capital } \\
\text { goods based on R\&D and innovative ac- } \\
\text { tivities }\end{array}$ & $-0,155$ & $\begin{array}{l}\text { 3. Accelerated depreciation of } \\
\text { capital goods based on R\&D and } \\
\text { innovative activities }\end{array}$ & $-0,155$ \\
\hline $\begin{array}{l}\text { 4. No tax credit based on expen- } \\
\text { ditures on R\&D and innovative } \\
\text { activities }\end{array}$ & 0,616 & $\begin{array}{l}\text { 4. Tax credit based on total ex- } \\
\text { penditure on R\&D an innovative } \\
\text { activities }\end{array}$ & $-0,616$ \\
\hline $\begin{array}{l}\text { 5. No tax exemption based on collaborative } \\
\text { innovative activities }\end{array}$ & $-0,474$ & $\begin{array}{l}\text { 5.Tax exemption based on innovative } \\
\text { collaborative activities with other firms }\end{array}$ & $-0,937$ \\
\hline $\begin{array}{l}\text { 6. Guarantee funds for innova- } \\
\text { tion \& tech transfer projects }\end{array}$ & 0,714 & $\begin{array}{l}\text { 6. No guarantee funds for innovation } \\
\text { and tech transfer projects }\end{array}$ & $-0,7 / 4$ \\
\hline $\begin{array}{l}\text { 7. Public funds as subsidies for co-financ- } \\
\text { ing R\&D and other innovative activities }\end{array}$ & 0,167 & $\begin{array}{l}\text { 7. No public funds for co-financing } \\
\text { R\&D, tech transfer projects and } \\
\text { other innovative activities }\end{array}$ & $-0,249$ \\
\hline $\begin{array}{l}\text { 8. Tax deduction based on intellectual } \\
\text { property transfer among universities and } \\
\text { firms }\end{array}$ & 0,291 & $\begin{array}{l}\text { 8. No tax deduction based on IP } \\
\text { transfer among universities and } \\
\text { firms }\end{array}$ & $-0,291$ \\
\hline Total utility & 1,317 & $\begin{array}{c}\text { Total utility } \\
\end{array}$ & $-2,804$ \\
\hline
\end{tabular}

Table 9. Structure of preference of profiles $17 \& 18$

ISSN: 07I 8-2724. (http://www.jotmi.org) 


\section{Concluding remarks}

\section{Policy implications}

The analysis of preferences of incentives to innovation provided the opportunity to explore in depth and in different levels, the structure of preferences of Dominican firms. At the aggregate level of preferences, the most preferred attributes (tax exemption, depreciation and public funds) could anticipate a "crowding-out" effect of the public funding of the business expenditure in R\&D and other innovative activities. This means that the private efforts on innovation could be offset by the government dominance, which was highlighted by Park in the context of LAC countries (Park, 2002). Although in LAC countries the private support to $R \& D$ and other innovative activities has increased in recent years (RICYT, 20I0), the fact is that the public sector still is the main funder of R\&D (Arocena \& Sutz, 200I).

The structure of preferences that were found, could express a deep cultural background and dependency of public funding and also a learning path to take into account for STI policy making in the Dominican Republic, which is a late comer country in regards to STI policies in the context of LatinAmerican countries.

Identifying and analyzing the underlying patterns that could explain the preferences of Dominican firms is beyond the scope of this research, as these are related to the complex dynamics of learning in developing countries, including the technological paradigms and trajectories, which, in turn, depend on the STI institutional context (Breschi, Malerba, \& Orseingo, 2000).

It is important to remember that the surveyed firms develop their activities embedded in a particular STI institutional context with defined rules and placed restrictions on what firms can and cannot do, conditioning the possibilities of learning and the incorporation of new knowledge and innovations (Nelson \& Nelson, 2002).

In such institutional context, informal learning processes probably have more impact on the innovativeness of firms than the formal dynamics of R\&D. In the case the Dominican Republic, the innovativeness of firms could be conditioned by factors ranging from availability of human capital, technological infrastructure, linkages with universities and research centers to financing (Metcalfe \& Ramlogan, 2008). The ideological and cultural context related to STI policies of a developing economy such as the Dominican Republic may significantly condition the preferences of incentives to innovation of firms, and take the shape of mental models or conceptual maps that lead the decision making process (Denzau \& North, 1994).

\section{Regarding the use of the Conjoint Analysis}

Given the exploratory nature of this research, the selection of a CA based on ranking was correct, as well as the decompositional and partial contributions approaches. The results were consistent with the literature on CA as well as with the somewhat sparse literature on incentives to innovation in LAC countries.

The CA is not a methodological panacea for ex-ante evaluation of STI public policies on innovation, but can supplement other qualitative approaches such as focus groups, the Delphi method, and opinion surveys. As it has ben stated before, the advantages of the Conjoint Analysis methods is their capability as choice modeling tools. 


\section{References}

ALPIZZAR, F., Carlsson, F., \& Martinsson, P. (200I). Using choice experiment for non-market valuation. Goteborg, Sweden: Department of Economics. Goteborg University.

AROCENA, R., \& Sutz, J. (200I). Changing knowledge production and Latin American universities. Research Policy(30), I22 I-I234. doi: http://dx.doi.org//0.1016/s00487333(00)00I43-8

ATKINSON, R. D., \& Andes, S. (20II). Patent Boxes: Innovation in Tax Policy and Tax Policy for Innovation (pp. 22). Washington, D. C.: Information Technology and Innovation Foundation.

ATTALI, J. (2010). República Dominicana 2010-2030 (pp. 144). Santo Domingo: Ministerio de Economía, Planificación y Desarrollo.

BANCO-CENTRAL. (20I3). Estadísticas económicas. Retrieved 05/marzo/2013,2013, from http://www.bancentral. gov.do/estadisticas.asp?a=Sector_Real

BERGER, A. N., \& Udell, G. (1998). The economic of small business finance: the roles of private equitiy and debt markets in the financial growth cycle. Journal of Banking and Finance, 22(6-8), 613-673.

BOXALL, P.,Adamowicz,V., Swait, J.,Williams, M., \& Louviere, J. (1996). A comparation of stated preference methods for environmental valuation. Ecological Economics(18), 243-253.

BOYLE, K. J., Holmes, T. P., Teisl, M. F., \& Roe, B. (200I). A comparison of conjoint analysis response formats. American Journal of Agricultural Economics, 83(2), 44I-454. doi: http:// dx.doi.org/ I0.1 I I I/0002-9092.00168

BRESCHI, S., Malerba, F., \& Orseingo, L. (2000). Technological regimes and Schumpeterian patterns of innovation. The Economic Journal, II0(463), 388-4I0. doi: http://dx.doi. org/ I 0. I I I I/ I 468-0297.00530

CEPAL. (2008). La República Dominicana en 2030: hacia una nación cohesionada. Santiago, Chile: Comisión Económica Para América Latina y el Caribe (CEPAL). Secretaría de Estado de Economía, Planificación y Desarrollo (SEEPyD).

DENZAU, A. T., \& North, D. C. (1994). Shared mental models: ideologies and institutions. Kyklos (International Review for Social Science), 47(I), 3-3I. doi: http://dx.doi. org/ I0.1 I I I/j. I467-6435.1994.tb02246.x
DESHAZO, J. R., \& Fermo, G. (2002). Designing choice sets for stated preference methods: the effects of complexity on choice consistency. Journal of Environmental Economics and Management, 44(I), I23-I43. doi: http://dx.doi.org/10.1006/ jeem.200I.II99

DOMINGUEZ, A. M. (2008). The effects of fiscal incentives and public subsidies on private R\&D investment. Revista de Economía Pública(I84), 35-66.

DOOLEY, A. E., Smeaton, D. C., Sheath, G.W., \& Ledgard, S. F. (2009). Application of multiple criteria decision analysis in the New Zealand Agricultural Industry. Journal of MultiCriteria Decision Analysis( (6), 39-53. doi: 10.1002/mcda.437

EDQUIST, C., \& Johnson, B. (1997). Institutions and organizations in systems of innovation. In C. Edquist (Ed.), System of Innovation. Technologies, institutions and organizations (pp. 4I-6I). London, U. K.: Pinter.

GEANAKOPLOS, J. (1996). Three brief proofs of Arrow's imposibility theorem Discussion Paper II23RRR (PP. 7). New Haven, Conneticut: Cowles Foundation for Research in Economics. Yale University. .

GREEN, P. E., Krieger,A. M., \& Wind,Y. J. (200I). Thirty years of conjoint analysis: reflections and prospects. Interfaces, 3 I (3), 56-73. doi: http://dx.doi.org/I0. I 287/inte.3I.4.56.9676

GREEN, P. E., \& Srinivasan, V. (1978). Conjoint analysis in consumer research: issues and outlook. Journal of Consumer Research, 5(2), I03-123. doi: http://dx.doi. org/| 0.1086/20872I

GREEN, P. E., \& Srinivasan, V. (1990). Conjoint analysis in marketing: new developments with implication for research and practice. Journal of Marketing, 54(4), 3-19. doi: http:// dx.doi.org//0.2307//25/756

GUELLEC, D., \& van Pottelsberghe de la Potterie, B. (2002). R\&D and productivity growth: panel data analysis of 16 OECD countries. Economic Studies, 2001 (2), 103-126. doi: http://dx.doi.org/I0.1787/eco_studies-v200 I-art I 2-en

GUZMÁN, R., \& Ortíz, M. (2007).Tamaño, eficiencia y uso de la capacidad instalada en las pequeñas y medianas empresas de la República Dominicana (pp. 68). Santo Domingo, D. N.: FONDOMICRO.

GUZMÁN, R. M. (20II). Composición Económica Dominicana. El estrato de ingresos medios en el umbral del siglo XXI. (pp. I 19). Santo Domingo, D. N.: Ministerio de Economía, Planificación y Desarrollo. 
HANLEY, N., Mourato, S., \& Wright, R. E. (200I). Choice modelling approaches: a superior alternative for environmental valuation? Journal of Economic Surveys, I5(3), 435-462. doi: | 0. I | | |/4667-64|9.00|45

HANLEY, N., Wright, R. E., \& Adamowicz, V. (1998). Using choice experiment to value the environment. Environmnet and Resource Economics, I I (3-4), 4 13-428. doi:http://dx.doi. org/I0.1023/a: 1008287310583

HATZICHRONOGLOU, T. (1997). Revision of the HighTechnology Sector and Product Classification OECD Science, Technology and Industry Working Papers (pp. 25): OECD.

HAUSMANN, R., Hidalgo, C.A.,Jiménez,J., Lawrence, R., LevyYeyati, E., Sabel, C., \& Schydlowsky, D. (20I I). Construyendo un mejor futuro para la República Dominicana: herramientas para el desarrollo (pp. I I9). Santo Domingo: MEPyD.

HSU, C.-C., \& Sandford, B. A. (2007). The Delphi Technique: making sense of consensus. Practical Assesment, Research \& Evaluation, I2(10), I-7.

HUBER, J.,Wittink, D. R., Fiedler, J.A., \& Miller, R. ( 1993). The Effectiveness of Alternative Preference Elicitation Procedures in Predicting Choice. Journal of Marketing Research, 30(I), 105-I |4. doi: http://dx.doi.org//0.2307/3172517

HUBER, J., \& Zwerina, K. (1996). The importance of utility balance in efficient choice designs. Journal of Marketing Research, 33(3), 307-317. doi: http://dx.doi. org/ $|0.2307 / 3| 52 \mid 27$

LANCASTER, K. J. (1966). A new approach to consumer theory. The Journal of Political Economy, 74(2), I32-I57. doi: http://dx.doi.org//0.1086/259|31

LOUVIERE, J. J. (1988). Conjoint analysis modelling of stated preferences. A review of theory, methods, recent developments and external validity. Journal of Transport Economics and Policy, XXII(I), 93-II 9.

LOUVIERE, J. J., Hensher, D. A., \& Swait, J. D. (2010). Stated Choice Method.Analysis and Application (Ist ed.). New York: Cambridge University Press.

MACFADDEN, D. (1980). Econometric models for probabilistic choice among products. Journal of Business, 53(3-part 2), 13-29.
METCALFE, J. S., \& Ramlogan, R. (2008). Innovation Systems and the Competitive Process in Developing Countries. Quarterly Review of Economics and Finance, 48(2), 433-446. doi: http://dx.doi.org//0.1016/j.qref.2006.12.02I

NELSON, R. R., \& Nelson, K. (2002). Technology, institutions, and innovation systems. Research Policy, 3 I (2), 265-272. doi: http://dx.doi.org//0.1016/s0048-7333(0I)00I40-8

OECD. (2005). SME and Entrepreneurship Outlook (pp. 417). Paris: Organisation for Economic Co-Operation and Development.

ONE. (20II). VIII Censo Nacional de Población y Vivienda 2002. Retrieved 29 de Octubre 20II, 20II, from http:// www.one.gob.do/index.php? module $=$ articles\&func $=$ view\&c atid $=120$

ORR, S. K. (20I I). The private sector on public land: policy implications of a SWOT Analysis of Banff National Park. Journal of Natural Resources Policy Research, 3(4), 34I-354.

PARK, W. G. (2002). Institutions and incentives for R\&D: implications for LAC economies Working Paper Series (Pp. 85). Washington, D. C.: Department of Econimics. American University.

PICÓN PRADO, E., \& Varela Mallou, J. (2000). Segmentando mercados con análisis conjunto. Una aplicación al sector turístico. Psicothema, I2(2), 453-458.

PNUD. (20I4). Informe de Desarrollo Humano 2014. Sostener el Progreso Humano: Reducir vulnerabilidades y construir resiliencia (pp. 243). New York, USA: Programa de las Naciones Unidas para el Desarrollo.

RAMÍREZ HURTADO, J. M., Rondán Cataluña, F. J., \& Guerrero Casas, F. M. (2007). Selección de franquiciados mediante simulacion con análisis conjunto. Cuadernos de economía y Dirección de Empresas(3I), I7I-202.

RICYT. (20I0). Indicadores de Ciencia y Tecnología. Retrieved 02/07/2013, 2013, from http://www.ricyt.org/ index.php?option $=$ com_content $\&$ view $=$ article\&id $=\mid 49 \&$ Ite $\operatorname{mid}=3$

RIVAS SÁNCHEZ, C. (2007). Los incentivos fiscales a la innovación: una síntesis comparada. Boletín Económico del ICE(29I5), 13-24.

RIVAS SÁNCHEZ, C. (2008). Estructura de los incentivos fiscales a la innovación: estudio comparado. Cuadernos de Ciencias Económicas y Empresariales(55), 35-67. 
RIVERA DEÁN, A., González Tabares, E., Martín Santana, M. A., Oñate García, J. L., \& Sánchez Fernández, I. (2004). Aplicación del análisis conjunto en la priorización de una lista de espera quirúrgica. Cuadernos Econónicos de I. C. E.(67), 93-106.

SÁNCHEZ, M., \& Gil, J. M. (1998). Comparación de tres métodos de estimación del análisis conjunto: diferencias en las preferencias en el consumo de vino y en la segmentación del mercado. Estudios de Economía Aplicada(10), |3 |- 46.

SCHEAFFER, R. L., Mendenhall, W., \& Ott, R. L. (2007). Elementos de Muestreo (6 ed.). Madrid, España:Thomson Editores. Paraninfo, S.A.

SCOTCHMER, S. (2004). Innovation and Incentives. Cambridge, MA. United States: MIT Press Book.

SEN, A. K. (1977). Rational fools: a critique of the behavioral foundations of economic theory. Philosophy and Public Affairs, 6(4), 317-344.

STEVEN, J. P. (1980). Power of the Multivariate Analysis of Variance Tests. Psychological Bulletin, 88(3), 728-737. doi: http://dx.doi.org// 0.1037/0033-2909.88.3.728

VONORTAS, N. (2002). Building competitive firms: technology policy initiatives in Latin America. Technology in Society, 24(4), 433-459. doi: http://dx.doi.org/10.1016/s0160$791 \times(02) 00034-9$

WORLD-BANK. (2015). Dominican Republic. Retrieved 06/02/2015, 2015, from http://www.worldbank.org/en/ country/dominicanrepublic 


\section{Annex}

Annex I.

One-way ANOVA based on a priori segmentation

\begin{tabular}{|c|c|c|c|c|c|c|}
\hline \multicolumn{7}{|c|}{ One Way ANOVA } \\
\hline Profiles & Variance & Sum of square & $g l$ & $\begin{array}{l}\text { Root mean } \\
\text { square }\end{array}$ & $F$ & Sig. \\
\hline \multirow[t]{3}{*}{ Profile 1} & Inter-groups & 0,61 & 1 & 0,61 & 0,032 & 0,859 \\
\hline & Intra-groups & 6220,59 & 321 & 19,38 & & \\
\hline & Total & 6221,21 & 322 & & & \\
\hline \multirow[t]{3}{*}{ Profile 2} & Inter-groups & 12,99 & 1 & 12,99 & 0,479 & 0,489 \\
\hline & Intra-groups & 8711,00 & 321 & 27,14 & & \\
\hline & Total & 8723,99 & 322 & & & \\
\hline \multirow[t]{3}{*}{ Profile 3} & Inter-groups & 28,55 & 1 & 28,55 & 1,424 & 0,234 \\
\hline & Intra-groups & 6435,51 & 321 & 20,05 & & \\
\hline & Total & 6464,06 & 322 & & & \\
\hline \multirow[t]{3}{*}{ Profile 4} & Inter-groups & 3,58 & 1 & 3,58 & 0,185 & 0,667 \\
\hline & Intra-groups & 6198,92 & 321 & 19,31 & & \\
\hline & Total & 6202,50 & 322 & & & \\
\hline \multirow[t]{3}{*}{ Profile 5} & Inter-groups & 51,78 & 1 & 51,78 & 2,725 & 0,100 \\
\hline & Intra-groups & 6100,02 & 321 & 19,00 & & \\
\hline & Total & 6151,80 & 322 & & & \\
\hline \multirow[t]{3}{*}{ Profile 6} & Inter-groups & 3,20 & 1 & 3,20 & 0,192 & 0,661 \\
\hline & Intra-groups & 5339,65 & 321 & 16,63 & & \\
\hline & Total & 5342,85 & 322 & & & \\
\hline \multirow[t]{3}{*}{ Profile 7} & Inter-groups & 25,15 & 1 & 25,15 & 1,213 & 0,272 \\
\hline & Intra-groups & 6654,48 & 321 & 20,73 & & \\
\hline & Total & 6679,63 & 322 & & & \\
\hline \multirow[t]{3}{*}{ Profile 8} & Inter-groups & 17,07 & 1 & 17,07 & 0,878 & 0,349 \\
\hline & Intra-groups & 6243,03 & 321 & 19,45 & & \\
\hline & Total & 6260,10 & 322 & & & \\
\hline \multirow[t]{3}{*}{ Profile 9} & Inter-groups & 76,04 & 1 & 76,04 & 3,762 & 0,053 \\
\hline & Intra-groups & 6489,17 & 321 & 20,22 & & \\
\hline & Total & 6565,21 & 322 & & & \\
\hline \multirow[t]{3}{*}{ Profile 10} & Inter-groups & 115,39 & 1 & 115,39 & 5,970 & 0,015 \\
\hline & Intra-groups & 6204,56 & 321 & 19,33 & & \\
\hline & Total & 6319,95 & 322 & & & \\
\hline \multirow[t]{3}{*}{ Profile 11} & Inter-groups & 0,93 & 1 & 0,93 & 0,046 & 0,831 \\
\hline & Intra-groups & 6545,80 & 321 & 20,39 & & \\
\hline & Total & 6546,73 & 322 & & & \\
\hline
\end{tabular}

ISSN: 07 I8-2724. (http://www.jotmi.org) 


\begin{tabular}{|c|c|c|c|c|c|c|}
\hline Profile 12 & Inter-groups & 12,20 & 1 & 12,20 & 0,497 & 0,481 \\
\hline & Intra-groups & 7880,30 & 321 & 24,55 & & \\
\hline & Total & 7892,50 & 322 & & & \\
\hline \multirow[t]{3}{*}{ Profile 13} & Inter-groups & 5,65 & 1 & 5,65 & 0,230 & 0,632 \\
\hline & Intra-groups & 7888,03 & 321 & 24,57 & & \\
\hline & Total & 7893,67 & 322 & & & \\
\hline \multirow[t]{3}{*}{ Profile 14} & Inter-groups & 4,53 & 1 & 4,53 & 0,189 & 0,664 \\
\hline & Intra-groups & 7672,30 & 321 & 23,90 & & \\
\hline & Total & 7676,83 & 322 & & & \\
\hline \multirow[t]{3}{*}{ Profile 15} & Inter-groups & 51,57 & 1 & 51,57 & 2,100 & 0,148 \\
\hline & Intra-groups & 7883,83 & 321 & 24,56 & & \\
\hline & Total & 7935,39 & 322 & & & \\
\hline \multirow[t]{3}{*}{ Profile 16} & Inter-groups & 65,06 & 1 & 65,06 & 2,176 & 0,141 \\
\hline & Intra-groups & 9597,57 & 321 & 29,90 & & \\
\hline & Total & 9662,63 & 322 & & & \\
\hline
\end{tabular}


Annex 2.

One-way ANOVA based on post hoc segmentation

\begin{tabular}{|c|c|c|c|c|c|c|}
\hline \multicolumn{7}{|c|}{ One Way ANOVA } \\
\hline Profiles & Variance & $\begin{array}{l}\text { Sume of } \\
\text { square }\end{array}$ & $g l$ & $\begin{array}{c}\text { Root mean } \\
\text { square }\end{array}$ & $F$ & Sig. \\
\hline \multirow[t]{3}{*}{ Profile 1} & Inter-groups & 252,77 & 1 & 252,77 & 13,595 & 0,000 \\
\hline & Intra-groups & 5968,44 & 321 & 18,59 & & \\
\hline & Total & 6221,21 & 322 & & & \\
\hline \multirow[t]{3}{*}{ Profile 2} & Inter-groups & 319,84 & 1 & 319,84 & 12,216 & 0,001 \\
\hline & Intra-groups & 8404,15 & 321 & 26,18 & & \\
\hline & Total & 8723,99 & 322 & & & \\
\hline \multirow[t]{3}{*}{ Profile 3} & Inter-groups & 248,49 & 1 & 248,49 & 12,833 & 0,000 \\
\hline & Intra-groups & 6215,57 & 321 & 19,36 & & \\
\hline & Total & 6464,06 & 322 & & & \\
\hline \multirow[t]{3}{*}{ Profile 4} & Inter-groups & 492,11 & 1 & 492,11 & 27,663 & 0,000 \\
\hline & Intra-groups & 5710,39 & 321 & 17,79 & & \\
\hline & Total & 6202,50 & 322 & & & \\
\hline \multirow[t]{3}{*}{ Profile 5} & Inter-groups & 158,78 & 1 & 158,78 & 8,505 & 0,004 \\
\hline & Intra-groups & 5993,02 & 321 & 18,67 & & \\
\hline & Total & 6151,80 & 322 & & & \\
\hline \multirow[t]{3}{*}{ Profile 6} & Inter-groups & 564,50 & 1 & 564,50 & 37,922 & 0,000 \\
\hline & Intra-groups & 4778,35 & 321 & 14,89 & & \\
\hline & Total & 5342,85 & 322 & & & \\
\hline
\end{tabular}




\begin{tabular}{|c|c|c|c|c|c|c|}
\hline Profile 7 & Inter-groups & 1081,19 & 1 & 1081,19 & 61,992 & 0,000 \\
\hline & Intra-groups & 5598,44 & 321 & 17,44 & & \\
\hline & Total & 6679,63 & 322 & & & \\
\hline Profile 8 & Inter-groups & 13,51 & 1 & 13,51 & 0,694 & 0,405 \\
\hline & Intra-groups & 6246,59 & 321 & 19,46 & & \\
\hline & Total & 6260,10 & 322 & & & \\
\hline Profile 9 & Inter-groups & 161,74 & 1 & 161,74 & 8,108 & 0,005 \\
\hline & Intra-groups & 6403,47 & 321 & 19,95 & & \\
\hline & Total & 6565,21 & 322 & & & \\
\hline Profile 10 & Inter-groups & 193,95 & 1 & 193,95 & 10,163 & 0,002 \\
\hline & Intra-groups & 6126,00 & 321 & 19,08 & & \\
\hline & Total & 6319,95 & 322 & & & \\
\hline Profile 11 & Inter-groups & 679,67 & 1 & 679,67 & 37,186 & 0,000 \\
\hline & Intra-groups & 5867,06 & 321 & 18,28 & & \\
\hline & Total & 6546,73 & 322 & & & \\
\hline Profile 12 & Inter-groups & 723,82 & 1 & 723,82 & 32,411 & 0,000 \\
\hline & Intra-groups & 7168,68 & 321 & 22,33 & & \\
\hline & Total & 7892,50 & 322 & & & \\
\hline Profile 13 & Inter-groups & 2424,22 & 1 & 2424,22 & 142,276 & 0,000 \\
\hline & Intra-groups & 5469,45 & 321 & 17,04 & & \\
\hline & Total & 7893,67 & 322 & & & \\
\hline
\end{tabular}




\begin{tabular}{|l|l|c|c|c|c|c|}
\hline Profile 14 & Inter-groups & 2359,31 & 1 & 2359,31 & 142,423 & 0,000 \\
\hline & Intra-groups & 5317,52 & 321 & 16,57 & & \\
\cline { 2 - 6 } & Total & 7676,83 & 322 & & & \\
\hline Profile 15 & Inter-groups & 2070,04 & 1 & 2070,04 & 113,289 & 0,000 \\
\hline & & & & & & \\
\hline & Intra-groups & 5865,36 & 321 & 18,27 & & \\
\cline { 2 - 5 } & Total & 7935,39 & 322 & & & 0,000 \\
\hline & Inter-groups & 1364,13 & 1 & 1364,13 & 52,767 & \\
\hline
\end{tabular}


Annex 3.a

MANOVA based on a priori segmentation

\begin{tabular}{|c|c|c|c|c|c|c|c|}
\hline \multicolumn{8}{|c|}{ Multivariate tests } \\
\hline Activities & Effect & Test & Value & $F$ & $\begin{array}{c}D F \\
\text { hypothesis }\end{array}$ & DF error & Sig. \\
\hline \multirow[t]{36}{*}{ Manufacturing } & \multirow[t]{4}{*}{ Intercept } & Pillai's Trace & 0,853 & 52,485 & 16,000 & 145,000 & 0,000 \\
\hline & & $\begin{array}{l}\text { Wilks's } \\
\text { Lambda } \\
\end{array}$ & 0,147 & 52,485 & 16,000 & 145,000 & 0,000 \\
\hline & & $\begin{array}{l}\text { Hotelling's } \\
\text { Trace }\end{array}$ & 5,791 & 52,485 & 16,000 & 145,000 & 0,000 \\
\hline & & $\begin{array}{l}\text { Roy's largest } \\
\text { root }\end{array}$ & 5,791 & 52,485 & 16,000 & 145,000 & 0,000 \\
\hline & \multirow[t]{4}{*}{ Region } & Pillai's Trace & 0,253 & 0,847 & 48,000 & 441,000 & 0,757 \\
\hline & & $\begin{array}{l}\text { Wilks's } \\
\text { Lambda }\end{array}$ & 0,765 & 0,849 & 48,000 & 432,060 & 0,754 \\
\hline & & $\begin{array}{l}\text { Hotelling's } \\
\text { Trace }\end{array}$ & 0,284 & 0,850 & 48,000 & 431,000 & 0,752 \\
\hline & & $\begin{array}{l}\text { Roy's largest } \\
\text { root }\end{array}$ & 0,138 & 1,271 & 16,000 & 147,000 & 0,223 \\
\hline & \multirow[t]{4}{*}{ Tax regimen } & Pillai's Trace & 0,129 & 1,345 & 16,000 & 145,000 & 0,178 \\
\hline & & \begin{tabular}{|l} 
Wilks's \\
Lambda \\
\end{tabular} & 0,871 & 1,345 & 16,000 & 145,000 & 0,178 \\
\hline & & $\begin{array}{l}\text { Hotelling's } \\
\text { Trace }\end{array}$ & 0,148 & 1,345 & 16,000 & 145,000 & 0,178 \\
\hline & & $\begin{array}{l}\text { Roy's largest } \\
\text { root }\end{array}$ & 0,148 & 1,345 & 16,000 & 145,000 & 0,178 \\
\hline & \multirow{4}{*}{\begin{tabular}{|l} 
Age of the \\
firm
\end{tabular}} & Pillai's Trace & 0,242 & 1,256 & 32,000 & 292,000 & 0,168 \\
\hline & & $\begin{array}{l}\text { Wilks's } \\
\text { Lambda }\end{array}$ & 0,770 & 1,262 & 32,000 & 290,000 & 0,163 \\
\hline & & $\begin{array}{l}\text { Hotelling's } \\
\text { Trace }\end{array}$ & 0,282 & 1,269 & 32,000 & 288,000 & 0,159 \\
\hline & & $\begin{array}{l}\text { Roy's largest } \\
\text { root }\end{array}$ & 0,203 & 1,848 & 16,000 & 146,000 & 0,030 \\
\hline & \multirow{4}{*}{$\begin{array}{l}\text { Capital } \\
\text { composition }\end{array}$} & Pillai's Trace & 0,414 & 1,066 & 64,000 & 592,000 & 0,345 \\
\hline & & $\begin{array}{l}\text { Wilks's } \\
\text { Lambda }\end{array}$ & 0,642 & 1,066 & 64,000 & 569,925 & 0,347 \\
\hline & & $\begin{array}{l}\text { Hotelling's } \\
\text { Trace }\end{array}$ & 0,475 & 1,064 & 64,000 & 574,000 & 0,349 \\
\hline & & $\begin{array}{l}\text { Roy's largest } \\
\text { root }\end{array}$ & 0,218 & 2,020 & 16,000 & 148,000 & 0,015 \\
\hline & \multirow[t]{4}{*}{ Firms'size } & Pillai's Trace & 0,295 & 1,579 & 32,000 & 292,000 & 0,028 \\
\hline & & $\begin{array}{l}\text { Wilks's } \\
\text { Lambda }\end{array}$ & 0,725 & 1,583 & 32,000 & 290,000 & 0,028 \\
\hline & & $\begin{array}{l}\text { Hotelling's } \\
\text { Trace } \\
\end{array}$ & 0,352 & 1,586 & 32,000 & 288,000 & 0,027 \\
\hline & & $\begin{array}{l}\text { Roy's largest } \\
\text { root }\end{array}$ & 0,237 & 2,164 & 16,000 & 146,000 & 0,009 \\
\hline & \multirow{4}{*}{$\begin{array}{l}\begin{array}{l}\text { Principal } \\
\text { market }\end{array} \\
\end{array}$} & Pillai's Trace & 0,355 & 1,234 & 48,000 & 441,000 & 0,144 \\
\hline & & \begin{tabular}{|l} 
Wilks's \\
Lambda
\end{tabular} & 0,681 & 1,242 & 48,000 & 432,060 & 0,137 \\
\hline & & $\begin{array}{l}\text { Hotelling's } \\
\text { Trace }\end{array}$ & 0,418 & 1,250 & 48,000 & 431,000 & 0,131 \\
\hline & & $\begin{array}{l}\begin{array}{l}\text { Roy's largest } \\
\text { root }\end{array} \\
\end{array}$ & 0,238 & 2,189 & 16,000 & 147,000 & 0,008 \\
\hline & \multirow{4}{*}{$\begin{array}{l}\text { Technological } \\
\text { level } \\
\text { products/servi } \\
\text { ces }\end{array}$} & Pillai's Trace & 0,262 & 0,880 & 48,000 & 441,000 & 0,701 \\
\hline & & $\begin{array}{l}\text { Wilks's } \\
\text { Lambda }\end{array}$ & 0,758 & 0,879 & 48,000 & 432,060 & 0,703 \\
\hline & & \begin{tabular}{|l|} 
Hotelling's \\
Trace
\end{tabular} & 0,293 & 0,877 & 48,000 & 431,000 & 0,705 \\
\hline & & \begin{tabular}{|l|} 
Roy's largest \\
root
\end{tabular} & 0,145 & 1,335 & 16,000 & 147,000 & 0,184 \\
\hline & \multirow{4}{*}{$\begin{array}{l}\text { Life cicle of } \\
\text { products/servi } \\
\text { ces }\end{array}$} & Pillai's Trace & 0,294 & 1,000 & 48,000 & 441,000 & 0,478 \\
\hline & & $\begin{array}{l}\text { Wilks's } \\
\text { Lambda }\end{array}$ & 0,733 & 0,993 & 48,000 & 432,060 & 0,491 \\
\hline & & $\begin{array}{l}\text { Hotelling's } \\
\text { Trace }\end{array}$ & 0,329 & 0,985 & 48,000 & 431,000 & 0,504 \\
\hline & & $\begin{array}{l}\text { Roy's largest } \\
\text { root }\end{array}$ & 0,155 & 1,423 & 16,000 & 147,000 & 0,138 \\
\hline
\end{tabular}

ISSN: 07 I8-2724. (http://www.jotmi.org)

Journal of Technology Management \& Innovation (c) Universidad Alberto Hurtado, Facultad de Economía y Negocios. 
Annex 3.b

MANOVA based on a priori segmentation

\begin{tabular}{|c|c|c|c|c|c|c|c|}
\hline \multicolumn{8}{|c|}{ Multivariate tests } \\
\hline Activities & Effect & Test & Value & $F$ & DF hypothesis & DF error & Sig. \\
\hline \multirow[t]{36}{*}{ Services firms } & \multirow[t]{4}{*}{ Intercept } & Pillai's Trace & 0,674 & 13,444 & 16,000 & 104,000 & 0,000 \\
\hline & & $\begin{array}{l}\text { Wilks's } \\
\text { Lambda }\end{array}$ & 0,326 & 13,444 & 16,000 & 104,000 & 0,000 \\
\hline & & $\begin{array}{l}\text { Hotelling's } \\
\text { Trace }\end{array}$ & 2,068 & 13,444 & 16,000 & 104,000 & 0,000 \\
\hline & & $\begin{array}{l}\text { Roy's largest } \\
\text { root }\end{array}$ & 2,068 & 13,444 & 16,000 & 104,000 & 0,000 \\
\hline & \multirow[t]{4}{*}{ Region } & Pillai's Trace & 0,397 & 1,009 & 48,000 & 318,000 & 0,462 \\
\hline & & $\begin{array}{l}\text { Wilks's } \\
\text { Lambda }\end{array}$ & 0,652 & 1,001 & 48,000 & 310,116 & 0,477 \\
\hline & & $\begin{array}{l}\text { Hotelling's } \\
\text { Trace }\end{array}$ & 0,464 & 0,992 & 48,000 & 308,000 & 0,492 \\
\hline & & $\begin{array}{l}\text { Roy's largest } \\
\text { root }\end{array}$ & 0,219 & 1,448 & 16,000 & 106,000 & 0,134 \\
\hline & \multirow[t]{4}{*}{ Tax regimen } & Pillai's Trace & 0,219 & 1,826 & 16,000 & 104,000 & 0,037 \\
\hline & & \begin{tabular}{|l|} 
Wilks's \\
Lambda \\
\end{tabular} & 0,781 & 1,826 & 16,000 & 104,000 & 0,037 \\
\hline & & $\begin{array}{l}\text { Hotelling's } \\
\text { Trace } \\
\end{array}$ & 0,281 & 1,826 & 16,000 & 104,000 & 0,037 \\
\hline & & $\begin{array}{l}\text { Roy's largest } \\
\text { root }\end{array}$ & 0,281 & 1,826 & 16,000 & 104,000 & 0,037 \\
\hline & \multirow{4}{*}{$\begin{array}{l}\text { Age of the } \\
\text { firm }\end{array}$} & Pillai's Trace & 0,243 & 0,906 & 32,000 & 210,000 & 0,617 \\
\hline & & $\begin{array}{l}\text { Wilks's } \\
\text { Lambda }\end{array}$ & 0,772 & 0,898 & 32,000 & 208,000 & 0,628 \\
\hline & & $\begin{array}{l}\text { Hotelling's } \\
\text { Trace }\end{array}$ & 0,277 & 0,891 & 32,000 & 206,000 & 0,639 \\
\hline & & $\begin{array}{l}\text { Roy's largest } \\
\text { root }\end{array}$ & 0,159 & 1,040 & 16,000 & 105,000 & 0,422 \\
\hline & \multirow{4}{*}{$\begin{array}{l}\text { Capital } \\
\text { composition }\end{array}$} & Pillai's Trace & 0,638 & 1,269 & 64,000 & 428,000 & 0,090 \\
\hline & & $\begin{array}{l}\text { Wilks's } \\
\text { Lambda }\end{array}$ & 0,488 & 1,287 & 64,000 & 409,418 & 0,079 \\
\hline & & $\begin{array}{l}\text { Hotelling's } \\
\text { Trace }\end{array}$ & 0,815 & 1,305 & 64,000 & 410,000 & 0,068 \\
\hline & & $\begin{array}{l}\text { Roy's largest } \\
\text { root }\end{array}$ & 0,423 & 2,829 & 16,000 & 107,000 & 0,001 \\
\hline & \multirow[t]{4}{*}{ Firms'size } & Pillai's Trace & 0,331 & 1,300 & 32,000 & 210,000 & 0,142 \\
\hline & & $\begin{array}{l}\text { Wilks's } \\
\text { Lambda }\end{array}$ & 0,696 & 1,292 & 32,000 & 208,000 & 0,147 \\
\hline & & $\begin{array}{l}\text { Hotelling's } \\
\text { Trace }\end{array}$ & 0,399 & 1,285 & 32,000 & 206,000 & 0,153 \\
\hline & & $\begin{array}{l}\text { Roy's largest } \\
\text { root }\end{array}$ & 0,242 & 1,589 & 16,000 & 105,000 & 0,084 \\
\hline & \multirow{4}{*}{$\begin{array}{l}\text { Principal } \\
\text { market }\end{array}$} & Pillai's Trace & 0,337 & 0,838 & 48,000 & 318,000 & 0,769 \\
\hline & & \begin{tabular}{|l} 
Wilks's \\
Lambda \\
\end{tabular} & 0,695 & 0,840 & 48,000 & 310,116 & 0,764 \\
\hline & & $\begin{array}{l}\text { Hotelling's } \\
\text { Trace }\end{array}$ & 0,394 & 0,843 & 48,000 & 308,000 & 0,760 \\
\hline & & $\begin{array}{l}\text { Roy's largest } \\
\text { root }\end{array}$ & 0,222 & 1,469 & 16,000 & 106,000 & 0,125 \\
\hline & \multirow{4}{*}{$\begin{array}{l}\text { Technological } \\
\text { level } \\
\text { products/servi } \\
\text { ces }\end{array}$} & Pillai's Trace & 0,439 & 1,135 & 48,000 & 318,000 & 0,261 \\
\hline & & $\begin{array}{l}\text { Wilks's } \\
\text { Lambda }\end{array}$ & 0,620 & 1,125 & 48,000 & 310,116 & 0,276 \\
\hline & & $\begin{array}{l}\text { Hotelling's } \\
\text { Trace }\end{array}$ & 0,521 & 1,114 & 48,000 & 308,000 & 0,291 \\
\hline & & $\begin{array}{l}\begin{array}{l}\text { Roy's largest } \\
\text { root }\end{array} \\
\end{array}$ & 0,243 & 1,613 & 16,000 & 106,000 & 0,078 \\
\hline & \multirow{4}{*}{$\begin{array}{l}\text { Life cicle of } \\
\text { products/servi } \\
\text { ces }\end{array}$} & Pillai's Trace & 0,483 & 1,271 & 48,000 & 318,000 & 0,119 \\
\hline & & \begin{tabular}{|l} 
Wilks's \\
Lambda \\
\end{tabular} & 0,587 & 1,266 & 48,000 & 310,116 & 0,124 \\
\hline & & $\begin{array}{l}\text { Hotelling's } \\
\text { Trace }\end{array}$ & 0,589 & 1,260 & 48,000 & 308,000 & 0,129 \\
\hline & & $\begin{array}{l}\text { Roy's largest } \\
\text { root }\end{array}$ & 0,292 & 1,936 & 16,000 & 106,000 & 0,025 \\
\hline
\end{tabular}

ISSN: 07 I8-2724. (http://www.jotmi.org)

Journal of Technology Management \& Innovation (c) Universidad Alberto Hurtado, Facultad de Economía y Negocios. 